\title{
O AGIR FEMININO DE ANTÍGONA E ANITA GARIBALDI LEITURA TRANSVERSAL DE “O CLAMOR DE ANTÍGONA”
}

Fernando Honorato de Oliveira ${ }^{1}$

RESUMO: O texto aborda a relação de poder na relação mulher-sociedade, contrapondo uma personagem ficcional (Antígona) e uma personagem real (Anita Garibaldi) e suas perspectivas históricas, partindo de uma leitura da obra de Judith Butler, O Clamor de Antígona. A abordagem visa demonstrar que, apesar dos séculos, ainda há uma evidente relação de dominação na definição do papel da Mulher, que é hostilizada subliminarmente, para ser colocada como objeto social e não sujeito social.

PALAVRAS-CHAVE: Feminismo. Mulher. Anita Garibaldi. Antígona.

ABSTRACT: The text addresses the power relationship in the woman-society relationship, contrasting a fictional character (Antigone) and a real character (Anita Garibaldi) and their historical perspectives, starting from a reading of Judith Butler's work, Antigone's Claim. The approach aims to demonstrate that, despite the centuries, there is still an evident relationship of domination in the definition of the role of women, which is subliminally hostile, to be placed as a social object and not a social subject.

KEYWORDS: Feminism. Women. Anita Garibaldi. Antigone.

\section{Da possibilidade de um papel social da Mulher}

A História da Humanidade registra uma oscilação do papel da Mulher, ora como deusa e matriarca, assumindo preponderância nas ações sociais, ora sendo submissa e praticamente um objeto nas mesmas relações. Dessa incongruência a norte-americana Judith Butler promove uma reflexão a partir de fatos e fenômenos observáveis à luz de sua leitura da obra de Sófocles - Antígona.

Butler usa a personagem como integrante de uma estrutura em que as leis da família e dos deuses são a base para questionar as leis do Estado. A autora quer mostrar a incoerência das ações do rei Creonte com a lei divina, e, principalmente, a ruptura com a lei de parentesco (tanto em vida como na morte), pois a lei da família é a concretude da base social. E essa

\footnotetext{
${ }^{1}$ Doutorando em Filosofia pela Universidade Federal de Uberlândia-MG. Apoio: Coordenação de Aperfeiçoamento de Pessoal de Nível Superior (CAPES). Artigo recebido em 05/11/2019 e aceito em 18/11/2019.
} 
argumentação abre fissuras na abordagem de gênero, através de sua leitura desse texto de Sófocles.

Antígona é descrita por Butler como uma manifestação da força da feminilidade, que questiona o Estado pelo viés dialético, com argumentos lógicos e consistentes. O texto evidencia uma abordagem política e social que não se manifesta como um simples ato de rebeldia ou de revolta contra o Estado. Antígona se concretiza como figura política, desafiando Creonte, contestando seus argumentos, mesmo com o peso das implicações e consequências de tal ato. É possível afirmar que Antígona é a manifestação da Mulher que se posiciona politicamente com base em seus próprios valores, transcendendo a visão conservadora, conectando a transição de um momento pré-político para político; ela luta ao clamar pela justiça básica da lei de parentesco, vista como condição possível, inicial, de uma nova realidade que permita a reestruturação das leis do Estado.

O texto de Butler questiona a legitimidade da justiça do Estado, ao indagar qual a base da moralidade imposta à sociedade e, fazendo isso, expõe como tal cultura histórica se manifesta na elaboração de leis em que a Mulher é alienada, condenada ao silêncio, num processo de marginalização aceito como "normal". A figura feminina sequer é cidadã, pois é cerceada, sem representação e representatividade; assim, é crucial abordar o empoderamento feminino e sua manifestação social através da personagem. Quando Antígona rompe com sua condição de Mulher silenciada e questiona diretamente o rei Creonte, ela assume, socialmente, uma atitude viril, masculina - ao se manifestar através de um discurso questionador. Simultaneamente, ao ouvi-la, é possível inferir que ocorre uma emasculação de Creonte; e ele, após uma reflexão sobre os próprios atos, vê sua incoerência e tenta retroagir, buscando meios de salvar aquela que ele condenou. Essa situação demonstra a volatilidade da performance de gênero, pois, de acordo com a proposta de Butler, nenhuma das personagens está contida nos papéis originais (tradicionais?) de gênero.

A concretude dos atos sociais de Antígona pode ser entendida como defensora de valores éticos básicos, ao se alicerçar na certeza de manter os rituais das leis familiares e divinas, porém, é o seu clamor que se torna manifestação de liberdade, já que rompe com as convenções e altera as relações de gênero, expondo as incongruências de leis injustas, preconceituosas e sem fundamento moral. Portanto, o agir de Antígona não é mero enfrentamento ou rebeldia sem propósito, e sim um ato político, racional, exposto discursivamente, abalando logicamente padrões sociais impostos sem um fundamento ético 
efetivo, evidenciando que, às vezes, as ações do Estado podem ser legais, mas nem sempre são morais.

É crucial estabelecer tais pontos na minha leitura do livro de Butler, pois eles são a perspectiva adotada na elaboração deste texto, com desdobramentos que serão evidenciados a seguir.

As percepções dos possíveis papéis da Mulher na sociedade, considerando o Estado como fonte de manifestações opressoras desses papéis é um dos passos para estabelecer os horizontes deste trabalho. É necessário afirmar que comumente a Mulher não é objeto de trabalhos filosóficos específicos, com bases lógicas e coerentes para sua plena admissibilidade como protagonista social. Primordial também é estabelecer que os poucos registros sistemáticos dessa realidade nos permitem elaborar noções que definem uma limitada compreensão da barreira antropológica, psicológica e social construída ao longo de milhares de anos, restringindo os horizontes da Mulher como Ser. Evidentemente existem casos em que a Mulher foi citada - e até mesmo estudada - como fenômeno típico da condição humana, isto é, ela é reificada, torna-se uma "coisa" que pode ser avaliada a partir de visões distorcidas e preconceituosas, amparadas pela legalidade de comportamentos unilaterais exclusivamente masculinos e, porque não, machistas. Tais comportamentos estabeleceram padrões que se disseminaram entre as diferentes culturas, com efeitos que perduram até os dias atuais.

À medida que a humanidade foi evoluindo e as civilizações foram se estabelecendo, o conceito de Ser passou a ter nuances fundamentadas numa visão social mais completa e lógica, na qual não são apenas as características biológicas, físicas e sexuais que definem o Ser, mas a sua existência concreta e o seu agir ético e racional que estabelecem a sua validade ontológica. E tal conformação não pode ser ignorada, pois permeia o substrato no qual a atual civilização opera; por isso considero a herança greco-judaico-cristã na tradição filosófica ocidental como o cenário deste trabalho, sem desprezar ou ignorar as demais culturas ou abordagens sociais e políticas. Assim, a Mulher neste ambiente é um Ser que age, e seu agir é determinado pela conformação politicamente intencional de suas ações e pelo alcance de seu discurso, isto é, ela se impõe ou se submete mediante aquilo que fala ou silencia, conforme aquilo que faz. Se há uma possibilidade de transformar e transcender essa condição e situação, ela só é possível mediante uma ação clara, pessoal, direta e socialmente motivada. Butler consegue transpor essa realidade de forma clara em seu texto, sem 
pretender ser axiomática - a força de sua argumentação é suficientemente dialética para demonstrar isso.

\section{De um agir feminino}

Para os propósitos deste exercício, preliminarmente, considero que as primeiras formalizações teóricas do papel social da Mulher podem ser atribuídas a Demócrito de Abdera, de cuja obra cito um fragmento: "Não se exercite a mulher na palavra; pois isso é coisa perigosa." ${ }^{2}$ Esse fragmento e outras citações de Demócrito, conforme minha leitura de A Política de Aristóteles, me parecem um evidente fundamento de que a visão da Mulher entre os gregos foi objeto de estudo, porém buscando restringir seu papel ao de fornecedora de prazer sexual e meio de reprodução, ou pouco mais que isso. Também é necessário evidenciar como as leis gregas viam a Mulher, sob uma perspectiva estritamente jurídica. $\mathrm{Na}$ Constituição de Atenas ela é colocada junto às crianças, no final da escala social: "Não era apenas o governo que era oligárquico, em todos os seus aspectos, mas também, todas as pessoas humildes, homens, mulheres e crianças eram servas dos ricos."3

Considerando que essa forma de ver a Mulher era mais evidente entre os atenienses que entre os espartanos; de modo geral a Mulher era apenas uma criatura à disposição do homem para ser usada conforme este quisesse. Embora o texto de Sófocles seja ambientado em Tebas, o contexto sociocultural é o mesmo. Citando novamente a Constituição de Atenas, é evidente a tentativa de silenciar a Mulher, impondo-lhe mordaças jurídicas, como se apreende da seguinte citação:

Ao fazerem isso diziam que restabeleciam a Constituição, livrando-a de tenebrosidades, tais como: deixar em liberdade absoluta o que testava instituindo herdeiros a seu gosto, e abolir as limitações existentes em caso de loucura, velhice e influência feminina indébita, com o fim de não deixar resquício por onde pudessem se infiltrar os acusadores profissionais. $^{4}$

Fica evidente que a presença da Mulher no contexto social era algo indesejado, sendo ela apenas objeto de cuidado caso estivesse grávida: “Também é o Arconte quem cuida dos órfãos e pupilos do Estado, bem como das mulheres viúvas, cujos maridos, ao morrer, as

\footnotetext{
${ }^{2}$ Coleção Os Pensadores: Pré-Socráticos, pag. 281, citação 110.

${ }^{3}$ ARISTÓTELES. A Constituição de Atenas, cap. II - sublinhado meu.

${ }^{4}$ ARISTÓTELES. A Constituição de Atenas, cap. XXXIV - sublinhado meu.
} 
tenham deixado grávidas." ${ }^{5}$ Desse modo, a envergadura do desafio de Antígona é bem demonstrada, já que suas ações e seu discurso se tornam praticamente subversivos, pois a Mulher era(?) vista como criatura submissa, sem vontade e alienada da estrutura politicamente decisória.

É este o ponto de partida da leitura de Butler, observando que a Mulher, tomada como arquétipo de um Ser político, ontologicamente definido pela palavra/discurso, precisa ter seu papel visto a partir desse condicionante social. A Mulher, como ser político, só existe, concretamente, quando fala, quando seu discurso assume uma função política. Eis o cerne do papel questionador de Antígona que, ao violar o decreto real que nega as honras fúnebres a seu irmão Polinices, assume publicamente o papel de oposição ao rei Creonte, seu tio. Mas como se dá essa oposição? Pela ação de sepultar o irmão, em primeiro lugar, ficando a oposição estabelecida politicamente pela palavra, pelo discurso que exige um agir consciente que contraria a visão corrente da Mulher submissa e alienada do processo social dominado pelo homem.

Seja um Estado despótico ou não, existe uma relação legal e, portanto, política e social, no enfrentamento que Antígona faz ao rei Creonte. Esse enfrentamento é baseado na tradição religiosa helênica, em que Antígona aponta uma incoerência entre o édito do rei e os mandamentos "divinos" - fonte da justiça - que determinam o respeito para com os mortos pelo dever religioso e social de praticar os ritos fúnebres em homenagem aos parentes falecidos. Tal lei "divina" foi considerada pelo próprio rei Creonte, ao determinar que as honras do sepultamento deveriam ser prestadas a Etéocles. Ora, se ambos eram irmãos, se enfrentaram numa luta aberta e leal, e ambos morreram, por que negar a um o que foi permitido a outro? Antígona expõe de forma clara essa incoerência da determinação real, cuja consequência é a punição pelos deuses, quando diz que: “E não seria por temer homem algum, nem o mais arrogante, que me arriscaria a ser punida pelos deuses por violá-las." 6

A interpretação que Antígona faz da atitude do rei Creonte, me parece expor a opção política deste diante do que, para ela, é uma tragédia familiar. Para ele a morte de Etéocles parece representar a perda de um aliado político, de um líder militar, e não de um sobrinho. Por outro lado, para ela a morte de Polinices tem uma perspectiva de perda dupla, pois além do irmão, ela também pode perder as bem-aventuranças do paraíso dos deuses se não cumprir

\footnotetext{
${ }^{5}$ ARISTÓTELES. A Constituição de Atenas, cap. LIV.

${ }^{6}$ SÓFOCLES. A Trilogia Tebana: Édipo Rei-Édipo em Colono-Antígona.: p. 223, citação 520.
} 
com o dever religioso. Observa-se nas palavras de Antígona uma crítica direta ao rei, pois ela o chama de arrogante e insensato, já que conhecendo as leis dos deuses decide ir contra elas, mesmo sabendo que está agindo contra a própria família, movido por seus interesses políticos. E este é um dos divisores de perspectivas, conforme nos permite a leitura de Butler.

O discurso de Antígona assume um caráter político também pelo posicionamento que o rei Creonte adota, ao conferir às palavras dela uma envergadura "masculina", explicitando a misoginia de sua reação. Se ela não for punida, é a masculinidade dele que será posta em jogo. Vale destacar que ele também quer punir a irmã de Antígona, Ismene, acusando-a de cumplicidade no delito de desobediência. Fica evidente que se houver mais de uma pessoa envolvida na ação, configura-se um ato político por excelência, um complô, uma articulação para desobedecer a autoridade real. Ficando a ação restrita a uma só pessoa - mesmo sendo uma Mulher - tal ato pode ser controlado, mas o exemplo dela é subversivo porque contestador e pode induzir outros a questionarem sua autoridade, seja por ações ou por palavras.

Porém o discurso de Antígona mostra que mesmo os cidadãos vêm Creonte como um tirano, silenciando quando ele surge, temerosos de manifestarem aquilo que pensam a respeito do rei. Ora, se os tebanos não falam é porque temem por suas vidas, mas ela não tem esse sentimento, seu posicionamento é o de quem sabe que sua ação lhe custará a vida e não tem medo disso. No diálogo entre ambos ela mostra que aqueles que morreram, morreram como irmãos, sujeitos às leis da própria morte. Embora Creonte queira tergiversar com ela, usando a lei como base, Antígona destrói os argumentos afirmando que: "Nasci para compartilhar amor, não ódio." 7 Por tal proposição, Creonte é obrigado a assumir uma posição de ataque frontal, pois se vê acuado pelo discurso dela, dizendo: "Não me governará jamais mulher alguma enquanto eu conservar a vida!" ${ }^{8}$ Ora, fica evidente que embora o conteúdo dessas palavras de Antígona seja tipicamente feminino, falando do amor e do respeito aos deuses, Creonte sente-se ameaçado pelo vigor do discurso, alicerçado em argumentos não-contraditórios - portanto uma característica "masculina". Esse aspecto do discurso de Antígona é percebido pelo rei como ameaça a seu reinado e a seus valores pessoais, daí recusa-se a aceitar o discurso deuma Mulher, embora a motivação política

\footnotetext{
${ }^{7}$ SÓFOCLES. A Trilogia Tebana: Édipo Rei - Édipo em Colono - Antígona.: p. 223, citação 595.

${ }^{8}$ SÓFOCLES. A Trilogia Tebana: Édipo Rei-Édipo em Colono - Antígona.: p. 223, citação 600.
} 
continue sendo o pano de fundo das circunstâncias descritas por Sófocles, de acordo com a leitura de Judith Butler.

Diante dessa flagrante contestação a sua autoridade, Creonte não tem alternativa a não ser punir Antígona com a morte, mesmo sabendo que isso irá causar dor em sua família, devido ao relacionamento desta com seu filho Hêmon. $\mathrm{O}$ aspecto despótico da decisão do rei evidencia mais que uma reação preconceituosa ao discurso de Antígona, já que este promove uma ruptura contestatória e subversiva com o estereótipo feminino, praticamente impondo a dureza das ações repressoras. $\mathrm{O}$ ato transgressor de Antígona se torna uma afronta à autoridade de Creonte, pois os termos de seu próprio discurso evidenciam que mais que uma ação "ilegal”, o ato dela passa a ser politicamente subversivo e precisa ser punido rigorosamente porque ela o defende em termos "masculinos", argumentando e apresentando razões num discurso tipicamente "de homem".

Desta perspectiva, o posicionamento de Butler para manter sua coerência, exige uma abordagem do ambiente sócio familiar em que Antígona de Sófocles é mais que o relato de uma tragédia familiar que se inicia com Édipo e Jocasta. Para Butler, uma visão simultaneamente atemporal e histórica da obra sugere uma possível interpretação filosófica e antropológica do texto, já que $O$ Clamor de Antígona questiona se a repressão à Mulher acontece num contexto cultural em que os problemas são aceitos como parte da estrutura social, de uma normalidade familiar independente da época. Essa leitura atemporal do personagem Antígona me permite tomá-la como referencial para considerar seu posicionamento como de uma precursora (ainda que ficcional) do feminismo atual, em que a visão política do agir feminino extrapola os limites do discurso.

Antígona não pretende questionar o rei apenas e tão somente por um posicionamento político de oposição, sua ação é motivada pelo amor que sente pelo irmão, por sua convicção interna de que age em sintonia com os valores nos quais acredita e com os quais nasceu e cresceu, tendo sido educada por eles. Sua revolta contra o édito de Creonte implica em sua tácita sujeição a uma lei maior, apoiada no amor, de acordo com as tradições sociais e culturais em que ela vive.

Conforme permite a leitura de Butler, posso afirmar que a Mulher de ação tem que assumir um posicionamento político em que seu discurso seja coerente com os valores que acredita, sejam eles em acordo ou em oposição ao Estado. A ação feminina, histórica e 
politicamente efetiva, só é possível e viável se houver um objetivo que busque melhorar o posicionamento da Mulher na sociedade. E um paradigma desse posicionamento encontrei na história de vida de Anna Maria de Jesus, mais conhecida como Anita Garibaldi.

\section{O feminino e a luta contra o autoritarismo}

Se o texto de Judith Butler considera a personagem fictícia Antígona uma possível precursora do feminismo, como podemos avaliar uma Mulher real, que rompeu com o modelo submisso vigente em sua época e tornou-se a "heroína de dois mundos"? Para isso precisamos delinear o cenário histórico da vida dessa Mulher.

Até onde se sabe, Anna Maria de Jesus casou-se aos 14 anos com um sapateiro, com quem viveu pouco mais de 3 anos, num relacionamento infeliz. O marido, Manuel Duarte de Aguiar, deixou-a para alistar-se no Exército Imperial, que à época combatia a nascente Revolta Farroupilha. Anna, chamada pela família de "Aninha", mudou-se então para a casa dos pais, em Laguna - SC. Em outubro de 1839, um navio atracou no porto da cidade, e um marinheiro de luneta observando o porto viu um grupo de moças passeando e ficou encantado com uma delas. Esse marinheiro era Giuseppe Garibaldi italiano que vinha ao Brasil para lutar ao lado dos revoltosos gaúchos que queriam criar a República RioGrandense, no episódio que ficou conhecido como Revolta Farroupilha ou Guerra dos Farrapos. Após desembarcar, procurou-a, sem sucesso. Cansado, aceitou o convite de um dos moradores da cidade para um café e ao entrar na casa encontrou lá a moça que o encantara. Aproximando-se dela, olhou-a longa e fixamente e disse: "Tu devi esser mia!" (Tu deves ser minha, em italiano). Como Garibaldi não conseguia pronunciar "Aninha", chamou-a de Anita, e assim ela passou para a História.

Desse modo iniciou-se uma história de amor que teve um profundo impacto no Brasil e principalmente na Itália. E nessa história de amor encontramos elementos que permitem uma reflexão do papel da Mulher numa sociedade machista e que reduzia (ou ainda reduz?), o feminino a um papel subalterno e inexpressivo. Anita é uma figura ímpar num universo masculino, tanto no cenário público quanto privado, onde a guerra, espaço tipicamente masculino é o pano de fundo de uma ruptura com os elementos característicos da sociedade patriarcal conservadora dominante. Para apoiar minha interpretação da trajetória de vida da

\footnotetext{
${ }^{9}$ DUMAS, Alexandre. Memórias de Garibaldi: cap. 18.
} 
Mulher Anita, usarei a Tese de Doutorado de Fernanda Aparecida Ribeiro como referencial teórico, já que encontrei argumentos consistentes no texto, coerentes com a minha investigação. Vale observar que essa tese se transformou num livro de sucesso ("Anita Garibaldi coberta por histórias” - Editora Cultura Acadêmica/UNESP, 2012).

A Mulher Anita, amante apaixonada, abandona a família, a vida de casada (pois não havia a comprovação do destino do homem com o qual havia se casado), para seguir o italiano revolucionário, guerreiro, visionário, que veio em busca de construir uma nova realidade social: transformar aquela região do Brasil em uma República. O imperialismo conservador da época, além de pretender manter o país sob um regime de separação das pessoas por classes sociais e cor da pele, também estabelecia as condições para uma dominação econômica que espoliava as pessoas e assegurava privilégios. A Mulher era tratada como objeto, um ser que poderia ser chamado de secundário, pois seus direitos eram praticamente nulos e ela não possuía o acesso aos meios de transformar a própria realidade. Diante desse paradigma social, Anita vai ao mundo, rompendo com o modelo conservador, porém cabe destacar que essa ruptura acontece num ambiente dominado pela performance masculina, e sua ação assume essa característica, já que, literalmente ela vai à guerra lutar nas mesmas condições que os homens. E essa atitude escandalosa e agressiva para os padrões da época, provoca simultaneamente a rejeição dos conservadores, a admiração dos seus pares e a criação de um novo paradigma de comportamento social e político da Mulher. Essa interpretação que faço é compartilhada por Fernanda A. Ribeiro pois ela afirma que "se trata de uma mulher que rompe com as regras que estabelecem a opressão feminina e emerge em um espaço vetado às mulheres" (RIBEIRO, p. 10, 2010).

A primeira descrição de Anita é feita pelo prisma masculino, conforme relato feito por Garibaldi a Alexandre Dumas. Desse relato ressaltam, de um lado os ideais políticos de Giuseppe Garibaldi, e de outro lado o amor de uma Mulher que se dispõe a lutar junto com ele não apenas por uma justa causa social, mas para provar que ela também é capaz de guerrear como um bom soldado, sem abrir mão de sua condição de Mulher, sem abdicar do feminino. Anita e Giuseppe amaram, lutaram, tiveram filhos, numa história de vida e amor que, de tantos episódios, parece mais um romance que a realidade - o que, entretanto, não é o foco do presente trabalho

Conforme os relatos históricos, na Batalha da Laguna, quando as forças imperiais atacaram os revoltosos, Anita, tripulando um pequeno barco, transportou munições em meio 
ao fogo cruzado, permitindo que os soldados de Garibaldi pudessem resistir e afastar o ataque. Essa mostra de coragem e bravura, que é costumeiramente atribuída aos homens, evidencia que juntamente com o amor, Anita desenvolve a técnica de lutar e se esquivar dos ataques, cumprindo uma missão crucial naquele momento.

Se considerarmos que as motivações políticas de Garibaldi, somadas ao ambiente social tenso e violento naquela ocasião, poderiam causar a morte de ambos por se oporem ao poder constituído, identificamos que o enfrentamento de Antígona, transgredindo a lei, encontra um eco na realidade vivida por Anita. A distinção é que enquanto Antígona assume uma performance política que ameaça o poder do rei, pelo amor ao irmão - incestuoso ou não - aqui há um amor mais convencional, digamos, porém com um viés contestatório e assumidamente rompendo com os padrões vigente à época.

Se para Antígona o discurso é o instrumento de ruptura e contestação, em que seu posicionamento é marcado pela palavra e pela argumentação, sendo fundamentado num amor nascido sob o sinal da tragédia; para Anita a contestação é em si mesma um ato de amor, sob um posicionamento político que transcende os limites da sua relação com Garibaldi. De um lado a ação marcada pelo discurso masculino, porém seguida por uma espécie de oposição passiva, consciente de que seu ato será punido com a morte, independentemente de suas motivações. De outro lado o agir tipicamente masculino, pegando em armas, lutando, enfrentando de igual para igual o poder do Estado, revidando os ataques, porém consumando o papel da Mulher como amante e mãe. Essa peculiaridade das ações de Anita, aproximam mais que distanciam sua performatividade daquela de Antígona. Não é o sexo em si, mas o gênero de suas ações que as coloca num mesmo patamar. Ambas assumem o risco da morte, numa configuração simultaneamente trágica e heroica, em que a audácia de seus atos manifesta uma racionalidade que permite a construção de um agir cultural, político e social, configurado por ações tipicamente masculinas fundamentadas num amor que as transfigura e que parece loucura, conforme os padrões aceitos na época.

Se Antígona assume uma postura subversiva e conflituosa através de uma única ação, confirmada por um discurso político coerente e contestatório - agressivo até, Anita inverte essa conformação: seu agir é agressivo e seu discurso é delicado; porém os efeitos são similares. Ao ser presa durante a Batalha de Curitibanos, onde ela mais uma vez transportava munição para os soldados, Anita é informada que Giuseppe havia sido morto (o que não era 
verdade), e consegue comover o comandante das forças imperiais pedindo para encontrar o corpo do marido, no que ela consegue fugir e reencontra-lo em Vacaria, no Rio Grande do Sul.

A aparente fragilidade da Mulher, tanto em Antígona quanto em Anita, pode sugerir que ambas são movidas por uma espécie de atavismo feminino, em que o sentimento é o único motor de suas ações. Mas observando as ações de ambas encontramos uma consciência de seu agir como elemento transformador do mundo. Ambas assumem o seu amor e o risco de morrer, ambas se entregam por inteiro a uma luta em que sabem que seu adversário é mais forte, mas nem por isso deixam de lutar - sua força vem de seu amor, a sua feminilidade não é uma desvantagem: é o diferencial que lhes permite uma relação simbólica com o mundo, através de um agir que está acima do gênero, pois sua subjetividade está além de suas práticas.

A rebeldia de Antígona e Anita pode ser vista simultaneamente como objeto de admiração e repúdio, pois elas enfrentam a ordem vigente e assumem um papel de combate ao autoritarismo e a leis que consideram injustas. Sob o prisma histórico, ambas representam uma transição para a construção de um substrato social que precisa determinar novas regras para se manter. A coerência de Antígona com aquilo que considera certo e justo - as leis divinas - se apresenta em Anita como a luta para transformar um ambiente social e político marcado pela escravatura e pela exploração econômica dos pequenos produtores rurais. E ambas podem ser repudiadas pelos conservadores porque transgridem as regras convencionadas para o agir feminino, segundo eles, provando que é possível construir um padrão comportamental diferenciado que abala as estruturas de repressão e controle social imposto à Mulher.

Há uma repressão que impõe regras e valores que ambas contestam; pois, o Estado lhes nega voz e direito a se manifestarem como cidadãs. Sendo o Estado uma manifestação política por natureza, e a política é marcada pelo diálogo, a ambas é negado esse direito de dialogar. Antígona e Anita não se submetem às razões do Estado, (e a perspectiva de Butler fundamenta esta afirmação), já que este as aliena e não as reconhece como integrantes da sociedade. A elas resta, como alternativa para se afirmarem como seres ontologicamente definidos, a luta e a revolta, manifestas pelo discurso em Antígona e pelo recurso às armas em Anita. 
Se a sociedade masculina, viril e machista as aliena e reprime, elas são compelidas a se posicionarem, sob pena de deixarem de existir como pessoas. A repressão a elas imposta, (conforme a leitura que Butler faz de Lacan), determinaria uma sublimação de seus desejos e opiniões, fazendo com que elas tivessem que se anular como seres humanos racionais para aceitarem aquele estado de coisas. Essa anulação ontológica as transformaria em meros objetos do autoritarismo do poder constituído, apenas duas criaturas apáticas e sem voz, criaturas sem existência concreta. Porém elas rejeitam essa imposição: Antígona pelo discurso performaticamente masculino e politicamente agressivo, e Anita pela ação armada e violenta, segundo a perspectiva historicamente limitada de seus contemporâneos. É importante observar que Anita, antes de mesmo de ir viver com Giuseppe, já tinha o comportamento justo e a ética defensora de suas convicções e valores, conforme diz Fernanda A. Ribeiro: "Não importa qual o status social do opressor: a protagonista não se intimida e desafia destemidamente aqueles que oprimem o povo." (RIBEIRO, p. 90, 2010).

Mas há uma motivação nestas duas Mulheres que as faz transcender os limites dessa pretensa nulidade ontológica: elas amam. Se o amor, neste caso, for considerado como motivador de um posicionamento político contestatório, encontramos a chave para abrir a porta que conecta as personagens. Antígona declara esse motivador ao dizer: "Nasci para compartilhar amor, não ódio". ${ }^{10}$ Eis aqui um dos aspectos mais relevantes da ação dela, pois o amor, tomado como manifestação típica do agir feminino (segundo a concepção conservadora e machista então vigente), é o catalisador de um processo político e social que configura as ações da Mulher. Antígona leva esse processo ao limite ao agir contrariamente às determinações do rei, e coloca a própria vida como preço a ser pago por esse posicionamento, pois quando ela diz “...basta que eu morra" ${ }^{11}$, evidencia a envergadura de seu ato, já que são os seus valores como pessoa e como cidadã (embora a lei lhe negue esse papel), que representam a afirmação de sua concretude ontológica. O seu discurso configura uma relação de luta contra uma lei injusta, fornecendo os requisitos lógicos para expor a incoerência de Creonte e a forma opressiva pela qual as estruturas regulatórias do poder exercem seu papel repressor.

Butler, citando Lévi-Strauss em relação ao incesto, considera que as regras sociais, impostas como normas de conduta e relações, determinam a passagem da natureza para a

${ }^{10}$ SÓFOCLES. A Trilogia Tebana: Édipo Rei - Édipo em Colono - Antígona.: p. 223, citação 595.

${ }^{11}$ SÓFOCLES. A Trilogia Tebana: Édipo Rei-Édipo em Colono-Antígona.: p. 225, citação 625. 
cultura, pois estabelecem vínculos estruturais que configuram o agir individual e social. Desse modo, o contexto em que vive Anita, por sua vez, impõe a consideração de um ambiente em transformação, talvez um menos estratificado que o de Antígona, porém mais rígido e igualmente agressivo, pois as regras sociais limitam rigidamente o agir feminino. Tanto é assim que o fato de Anita cavalgar como um homem - o que é uma vantagem para uma guerreira - é visto como algo escandaloso para a sociedade em que ela vivia, afinal dominar o cavalo era um símbolo de virilidade característico do homem. Além disso, Anita transita num ambiente masculino sem esconder a sua feminilidade, ao contrário, ela é exposta ao assumir seu papel de esposa de Garibaldi. Essa configuração de relacionamento, em que o homem e a Mulher vivem num ambiente comum, com valores semelhantes, com uma proximidade ontológica que os nivela e especialmente, porque ela tem um agir masculino, colocando a própria vida em risco. Se de um lado existem regras e normas sociais validadas pela tradição cultural, definindo um lugar subalterno para a Mulher, condicionando-a pela restrição de seus direitos e pela imposição autoritária de atitudes e comportamentos; de outro lado há a possibilidade de rompimento com tais regras, superando-as pelo exercício consciente dos próprios desejos e valores.

Os atos de Anita iniciam esse rompimento com o ambiente em que ela vivia quando decide acompanhar um homem pelo qual sente um amor que compõe uma nova perspectiva de vida. Amar Garibaldi, um estrangeiro, com outros costumes, oriundo de um outro contexto social e cultural, numa condição que pode ser chamada de ilegal e subversiva, pois tal era a condição jurídica dele no Brasil, era em si mesmo um ato de contestação e negação do status quo vigente. Em termos mais contemporâneos, é possível dizer que ele era um guerrilheiro lutando por ideais contrários à ordem vigente, propondo a derrubada de um governo autoritário e a constituição de um novo país, sob novos valores, mais democráticos e igualitários. A aproximação de ambos, através do sentimento mútuo, reforça tal ruptura com a autoridade paterna - por abandonar o contexto social e familiar em que vivia - e ao mesmo tempo uma ruptura ainda mais relevante que é com o Estado, ao decidir lutar contra o governo imperial.

A condição de rebelde pegando em armas, por si só seria suficiente para marcar o enfrentamento da soberania do Estado. Mas sendo Mulher, abandonando o ambiente familiar com seus valores culturais, Anita torna esse ato socialmente simbólico, pois o rompimento com a esfera do parentesco consanguíneo marca de forma irreversível o agir e a performance 
dela. Sua transgressão com todas as normas vigentes transforma o seu ato pessoal num símbolo que retrata a violência da autoridade masculina tradicional, embora motivado intrinsecamente por outra figura masculina - Giuseppe Garibaldi. O amor que é o catalisador dessa transgressão, fornece o elemento psicológico que permite elaborar uma reflexão sobre a transição da figura feminina de um elemento passivo e sem relevância, para um papel de destaque, social e historicamente. A Mulher faz a diferença - seu agir tanto em Antígona quanto em Anita altera a ordem do poder constituído, gerando subsídios para a construção de uma nova ordem social, mais universal e integradora, baseada no valor mais nobre do Ser Humano: o Amor.

Destaca-se aqui a realidade de vida de Anita Garibaldi que participa da libertação da terra de seu homem, mas não de sua própria pátria. Na Itália ela era uma mulher estrangeira, mãe de três filhos, tendo que lidar com as dificuldades de conviver com novos hábitos sociais, com um idioma diferente do seu e com uma vida cheia de dificuldades. Porém, ela teve a coragem de buscar viver conforme seus valores, de viver uma história de amor, que já foi objeto de livros, filmes e estudos os mais diversos. As lutas que ela e Garibaldi participaram construíram também a relação de ambos, pois em meio à guerra eles encontraram um no outro a própria paz. Garibaldi diz em suas Memórias que Anita era especial, pois era muitas mulheres ou todas as mulheres, e ela se entregava de corpo e alma à relação. Ele diz que ela o surpreendia, pois demonstrou várias vezes que não tinha medo de nada, enfrentou mares, nevascas e quase todo tipo de perigo para lutar ao lado dele. Engravidou cinco vezes e morreu cansada de tanta guerra. Apesar disso, pelo que sabe, ela era feliz, pois lutou a vida inteira por uma paz, que para si mesma só existia enquanto estava junto do homem a quem amou.

Antígona não teve esse direito, pois o mais básico dos direitos do Ser Humano lhe foi negado: o direito de amar e ser amada. E essa configuração autoritária do rei Creonte continua sendo um comportamento aceito, apoiado e até incentivado, para manter a Mulher sujeita à tutela de interesses que não são os seus. Uma das interpretações possíveis do que foi aqui exposto, é que a negação da identidade da Mulher como Ser ontologicamente definido, como cidadã, como profissional, como membro da sociedade plenamente aceita e ativamente participante dela, como pessoa completa enfim, principia pela negação daquilo que ela sente, pela proibição de sua existência como indivíduo que ama, que tem o direito 
de amar e ser amada, pela repressão ao que há de mais nobre e elevado na alma humana: o amor.

\section{O feminino e a realidade política}

Os papeis sociais feminino e masculino ao longo da História parecem ter sido sempre muito distintos. Porém, tais papéis englobam quais funções? O que se espera da Mulher e do homem em suas relações de sociedade? Naturalmente existem expectativas de comportamento, conforme os padrões culturalmente aceitos. Tais padrões precisam considerar a formação religiosa e intelectual de seus integrantes, a sua participação no mercado de trabalho, as condições físicas e de saúde, dentre outros parâmetros possíveis. Mas, principalmente, conforme o sexo de cada pessoa. Diante disso, as questões de gênero impõem condicionantes às relações sociais e aos papéis desempenhados de acordo com o sexo da pessoa. É inegável que o papel da Mulher tem sido objeto de desigualdade social, com evidente prejuízo para a figura feminina. Esse estado de coisas obriga a aceitação de que enquanto a conformação biológica define o sexo da pessoa; o gênero, isto é, a conformação de identidade feminina ou masculina de suas atitudes é resultado de um agir cultural e social, que resulta das condições de vida em sociedade. Considerando essas condições, os comportamentos de homem e de Mulher são mutáveis, conforme as variáveis históricas, culturais, políticas e sociais. Os diferenciais de sexo são parte integrante das civilizações, sendo que em algumas delas, como na tradição greco-judaico-cristã, a Mulher é vista como símbolo de ações pecaminosas, exigindo que ela seja objeto de controle, sujeição e até mesmo desprezo. Nas sociedades assumidamente patriarcais e machistas, a relação social da Mulher é sempre sujeita à tutela do homem, praticamente ignorando a sua realidade como ser autônomo e consciente. Exemplos dessas sociedades encontram-se na Ásia (Japão, China, Coréia do Norte, Índia, dentre outros países), mas os países ocidentais continuam mantendo esse modelo social, mesmo que travestido de discursos igualitários, como os países latinos e sul-americanos, Brasil incluso.

O ambiente familiar é determinante nesse cenário político, social e cultural que oprime a Mulher. Pais, irmãos, maridos e em alguns casos até os filhos, impõem à Mulher um padrão de comportamento submisso e alienado, obrigando-a a assumir posições não condizentes com a dignidade humana. A repressão social nem sempre é aberta ou assumida, 
porém ela existe, disfarçada sob os argumentos de "proteção ao sexo frágil", de restrições legais e jurídicas que limitam o acesso da Mulher ao mercado de trabalho ou a melhores condições profissionais e de vida. De Antígona a Anita Garibaldi e desta até os dias presentes, o cenário teve mudanças e avanços, mas a perspectiva cultural ainda não apresenta as condições reais que permita uma efetiva libertação da Mulher, para que ela assuma seu lugar como Ser e como cidadã.

Se em Antígona há uma tentativa de ordenamento pré-político, baseado nas relações familiares, religiosas e culturais, em que a performance discursiva masculina representa o enfrentamento da opressão, porém usando as mesmas estruturas vigentes; em Anita esse enfrentamento é construído pela consumação do papel da Mulher, que age de forma masculina ao pegar em armas e lutar, e, ao mesmo tempo possui uma relação consistente de mãe e esposa. Não que uma seja menos completa que outra, porém a Antígona o direito de ser esposa e mãe é negado, sua linhagem é interrompida nela. O Estado que a oprime retira dela a possibilidade de transmitir a seus descendentes os valores que ela acredita e pelos quais está dando a vida. Anita, ao lado de um homem, consegue transcender as barreiras da repressão do Estado, conquistando à força o direito de amar e ensinar a seus filhos os valores pelos quais está lutando. E neste ponto a transição de tais valores assume a relevância histórica através da qual hoje falamos de seus atos, pois eles foram passados adiante, permitindo que pudessem ser a base inicial de uma sociedade politicamente mais aberta, menos repressiva e mais tolerante. Ainda não temos, de fato, essa nova sociedade, mas seus valores já estão presentes, mesmo que reprimidos ou sublimados em vários momentos.

Para ambas as personagens o cenário político e social era o de pessoas despossuídas da própria vontade, pois que eram praticamente propriedades de seus reis, pais, irmãos ou maridos. A disposição de lutar e contestar a autoridade do Estado configura uma esfera legitimadora para uma nova ordem ética, pois se o preço a pagar por tal contestação é a vida, ele foi pago. Assim, não há justificativa para ignorar o que foi feito, o sacrifício realizado e o sofrimento imposto. A dor é o substrato do qual a Mulher consegue extrair as forças para superar a repressão e evidenciar a possibilidade de um modelo social menos agressivo e mais justo, pois Antígona e Anita constroem dentro de si as afirmações que demonstram essa verdade.

O universo masculino, contestado por essas personagens, é apresentado como um ambiente repressor e opressivo, condicionador e condicionante, marcado pelo preconceito e 
pela tirania, sob a questionável legitimidade das leis. Desse modo, a lei não é necessariamente a justiça, mas sim a manifestação do interesse das classes dominantes, interferindo na vida da Mulher como cidadã e impondo condições para o alcance da plenitude de sua vida social. Rompendo com tal condição, derrubando as barreiras de um sistema que asfixia e restringe, Antígona e Anita constroem um paradigma do agir feminino pautado pelo enfrentamento a um modelo injusto de sociedade, onde a Mulher ainda busca seu lugar.

A Mulher que morre vítima da opressão e da tirania, é a Mulher que nasce sob o símbolo da liberdade e da igualdade. Antígona, Cleópatra, Joana D’Arc, Anita Garibaldi, Rosa de Luxemburgo, Anne Frank, Olga Benário e inumeráveis outras Mulheres, reais e imaginárias, representam o limiar de uma nova relação de possibilidades através da qual é possível o acesso a uma nova realidade, cujas instâncias sociais e culturais estão além da esfera política, mas ao alcance da luta por sua transformação.

\section{REFERÊNCIAS}

ARISTÓTELES. Obras Completas. Volume VII - Política - Tomo I. Coordenação de António Pedro Mesquita. Lisboa: Imprensa Nacional Casa da Moeda. 2005.

ARISTÓTELES. A Constituição de Atenas. Tradução de A.S. Costa. Fonte: Editora Casa Mandarino - Rio de Janeiro - 29.07.2006. Disponível em:

<http://www.consciencia.org/aristoteles_constituicao_de_atenas.shtml > - Acesso em 27.11.2019.

BUTLER, Judith. O Clamor de Antígona: Parentesco entre a vida e a morte. Tradução de André Cechinel. Florianópolis: Editora UFSC. 2014.

DUMAS, Alexandre. Memórias de Garibaldi. Tradução de Antonio Caruccio-Caporale. Porto Alegre: L\&PM POCKET. 2006.

Coleção Os Pensadores. Pré-Socráticos. Supervisão: José Cavalcante de Souza. São Paulo: Editora Nova Cultural Ltda. 2000.

RIBEIRO, Fernanda Aparecida. Anita Garibaldi Coberta Por Histórias. 2010. 229f. Tese de Doutorado, Programa de Pós-Graduação em Letras, UNESP - Assis-SP.

SÓFOCLES. A Trilogia Tebana: Édipo Rei-Édipo em Colono - Antígona. Tradução de Mario da Gama Kury. Rio de Janeiro: Jorge Zahar Editor, $1^{\text {a }}$ edição, 1990. 